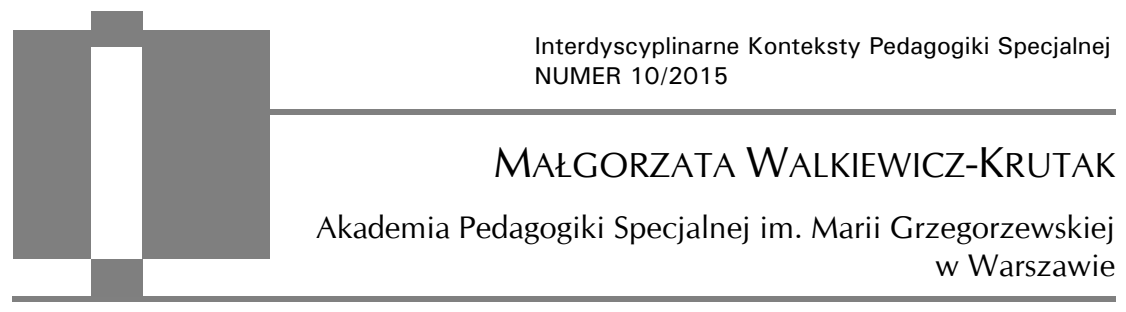

\title{
Wyzwania emancypacyjne w kontekście autonomii dorosłych osób z niepełnosprawnością wzroku
}

\begin{abstract}
Małgorzata Walkiewicz-Krutak, Wyzwania emancypacyjne w kontekście autonomii dorostych osób z niepetnosprawnościa wzroku [The challenges of emancipation in the context of autonomy of adults with visual impairment]. Interdyscyplinarne Konteksty Pedagogiki Specjalnej, nr 10, Poznań 2015. Pp. 111-126 Adam Mickiewicz University Press. ISSN 2300-391X

The aim of this article is to identify significant determinants of emancipation of persons with visual impairment. Ridding oneself of restrictions, stereotypes, and even violence affecting various spheres of functioning of a blind adult is crucial to the development and consolidation of his/her subjectivity. It is assumed that conscious autonomy of visually impaired people, enabling and conditioning performance of the tasks related to adulthood, requires independence in orientation and mobility, independence in carrying out activities of daily living, easy access to information and opportunities to communicate, undertaking satisfying professional activities as well as rewarding family, social and cultural activities. Developing subjectivity and autonomy in adulthood requires support from the family, as well as well-planned and consistently implemented educational and rehabilitation activities. The process of expanding autonomy of an individual can take place in relationship to the emancipation process of the group. One example is the activities of foundations run by visually impaired persons, whose main purpose is promoting dignified living of the blind.
\end{abstract}

KEY WORDS: emancipation, autonomy, subjectivity, persons with visual impairment, foundations 


\section{Wprowadzenie}

Paradygmat emancypacyjny jest we współczesnej pedagogice specjalnej przedmiotem zarówno dyskursu teoretycznego, jak i podejmowania działań praktycznych ukierunkowanych na edukację do emancypacji. Maria Czerepaniak-Walczak zdefiniowała emancypację jako proces

(...) świadomego odrzucania stereotypów i mitów, pokonywania utrudnień wywołanych aktywnością ludzką i siłami natury¹.

Zdaniem autorki istotnym wyróżnikiem współczesnej emancypacji jest jej podmiotowy wymiar:

Akcentowanie podmiotowego charakteru emancypacji zwraca uwagę na emancypowanie się, czyli świadomą, emocjonalną, werbalną i działaniową reakcję na społecznie unormowane zależności i stereotypy. W jej rezultacie możliwe jest osiąganie refleksyjnej, krytycznej świadomości, które wyraża się $\mathrm{w}$ samodzielnym dokonywaniu wyborów według podmiotowego systemu wartości, w odważnym, godnym wypowiadaniu własnych sądów i opinii oraz $\mathrm{w}$ odpowiedzialnym podejmowaniu działań prowadzących do doświadczania wolności².

Odpowiedzią na potrzebę wspomagania autonomii i podmiotowości osoby jest rozwój pedagogiki emancypacyjnej, która jest realizowana poprzez:

(...) tworzenie warunków rozwoju podmiotowego mówienia własnym głosem i świadomego uczestniczenia $\mathrm{w}$ zmienianiu siebie i swojego świata $(. . .)^{3}$.

Jednym z istotnych celów emancypacji osób z niepełnosprawnością jest wyzwolenie się $\mathrm{z}$ przedmiotowego traktowania (m.in.

${ }^{1}$ M. Czerepaniak-Walczak, Pedagogika emancypacyjna, Gdańskie Wydawnictwo Psychologiczne, Gdańsk 2006, s. 33.

2 Ibidem, s. 30.

3 Ibidem, s. 60 . 
w sferze oddziaływań edukacyjnych, rehabilitacyjnych, jak również w systemie rodzinnym, w środowisku społecznym i zawodowym) oraz dążenie do stawania się podmiotem aktywnym, świadomym własnej autonomii, własnych pragnień i możliwości ich realizacji.

Osoby z niepełnosprawnością, jak zaznacza Amadeusz Krause ${ }^{4}$, pomimo ograniczeń wynikających z dysfunkcji, mają możliwość rozszerzania swojej autonomii. Różnice w jej nabywaniu mogą wynikać ze stopnia niepełnosprawności, z rodzaju otrzymywanego wsparcia i ograniczeń jakie napotykają w procesie autonomii. Zdaniem Władysława Dykcika ${ }^{5}$ kluczowym elementem $\mathrm{w}$ osiąganiu autonomii przez osobę z niepełnosprawnością są uwarunkowania środowiskowe. Autonomia rozumiana jest przez autora jako podmiotowość człowieka w przestrzeni społecznej, m.in. jako samodzielność w wykonywaniu codziennych zadań, jako przejaw i rezultat procesu przystosowania, jako siła wyzwalająca własną aktywność jednostki oraz jako przygotowanie do życia w integracji społecznej. Amadeusz Krause ${ }^{6}$ wskazuje na rolę procesu normalizacji w rozwoju autonomii - przyjazne środowisko, korzystna sytuacja mieszkaniowa, zawodowa i społeczna - sprzyjają rozwojowi autonomii, a ich brak może ją uniemożliwiać. Autor podkreśla także znaczenie uczenia się autonomii i kształtowania umiejętności z nią związanych. Z kolei Beata Cytowska7 wskazuje na potrzebę edukacji i wychowania do emancypacji nie tylko osób z niepełnosprawnością, lecz także ich najbliższego środowiska - rodziny, przedszkola, szkoły, miejsca pracy.

${ }^{4}$ A. Krause, Wspótczesne paradygmaty pedagogiki specjalnej, Oficyna Wydawnicza „Impuls”, Kraków 2010, s. 203.

5 W. Dykcik, Problemy autonomii, integracji społecznej i normalizacji życia osób niepetnosprawnych w środowisku, [w:] Pedagogika specjalna. Praca zbiorowa, red. W. Dykcik, Wydawnictwo Naukowe Uniwersytetu im. Adama Mickiewicza, Poznań 2001, s. 365 .

${ }^{6}$ A. Krause, op. cit., s. 204.

7 B. Cytowska, Trudne drogi adaptacji. Watki emancypacyjne w analizie sytuacji dorostych osób z niepetnosprawnościa intelektualną we wspótczesnym społeczeństwie polskim, Oficyna Wydawnicza „Impuls”, Kraków 2012, s. 346. 
Wychodząc z założeń pedagogiki emancypacyjnej, Amadeusz Krause posługuje się terminem „specjalna pedagogika emancypacyjna", którą definiuje jako:

(...) zarówno indywidualne, jak i zbiorowe wyzwolenie osób niepełnosprawnych z dominacji pełnosprawności, z następstw, jakie ich dysfunkcja wywołuje $\mathrm{w}$ społeczeństwie, $\mathrm{z}$ utrudnień $\mathrm{w}$ funkcjonowaniu, jakie powoduje. Podstawą emancypacji jest nabywanie przez te osoby podmiotowości i autonomii, a na ich podstawie odzyskanie wolności, którą przez niepełnosprawność utraciły ${ }^{8}$.

\section{Autonomia a niepełnosprawność wzroku w dorosłości}

Autonomia w okresie dorosłości rozumiana jest tu przede wszystkim jako realizacja potrzeby niezależności w kierowaniu własnym działaniem i w decydowaniu o sobie, która dokonuje się poprzez stopniowe rozszerzanie autonomii we wcześniejszych okresach rozwojowych. Osiąganie autonomii przez osoby z niepełnosprawnością wzroku jest częścią procesu edukacyjno-rehabilitacyjnego i w czasie jego trwania wymaga kompromisu pomiędzy zależnością a autonomią. Jednym $\mathrm{z}$ istotnych aspektów autonomii jest dążenie do samodzielności wykonywania zadań życiowych i funkcjonowania pozbawionego zależności od pomocy i wsparcia innych.

Za Anną Brzezińską i Szymonem Hejmanowskim ${ }^{9}$ przyjęto, że autonomię osoby dorosłej warto rozważać w najistotniejszych obszarach funkcjonowania, czyli jako:

- autonomię dotycząca samoobsługi i zaspokajania podstawowych potrzeb,

- autonomię w wymiarze ekonomicznym,

8 A. Krause, op. cit., s. 208.

${ }_{9}$ A.I. Brzezińska, S. Hejmanowski, Okres późnej dorostości. Jak rozpoznać ryzyko i jak pomagać, [w:] Psychologiczne portrety człowieka, red. A.I. Brzezińska, Gdańskie Wydawnictwo Psychologiczne, Gdańsk 2005, s. 647-648. 
- autonomię w zakresie swobodnego przemieszczania się,

- autonomię dotycząca wyboru realizowanego stylu życia i sposobu dbania o jego jakość.

Możliwość samostanowienia i wolność w podejmowaniu decyzji życiowych w przypadku osób niewidomych wydaje się być bardzo mocno zależna od tych aspektów autonomii, które związane są $\mathrm{z}$ codziennym funkcjonowaniem. Dlatego autonomia dorosłych osób z zaawansowaną niepełnosprawnością wzroku (niewidzących lub posiadających możliwości wzrokowe ograniczone w znacznym stopniu) jest tu rozważana w kontekście umiejętności nabywanych i rozwijanych w procesie rehabilitacji i edukacji, które w decydującym stopniu warunkują niezależność funkcjonowania i decydowania o sobie.

Populację dorosłych osób z niepełnosprawnością wzroku cechuje silne zróżnicowanie ze względu na rozmaite aspekty. Niektóre z nich to: czas pojawienia się niepełnosprawności wzroku, poziom posiadanych możliwości wzrokowych i umiejętność korzystania z nich, możliwości i ograniczenia funkcjonowania psychospołecznego, poziom osiągniętej już autonomii, jak również poziom potrzeb w zakresie jej rozszerzania i rozwoju. Marzenna Zaorska10 zwraca uwagę na fakt, że poważne, a zwłaszcza całkowite, uszkodzenie wzroku może utrudniać, ograniczać, a czasem także uniemożliwiać realizację istotnych czynności związanych z życiem codziennym oraz rzutować na aktywność w różnych sferach funkcjonowania, np. w zakresie orientacji i przemieszczania się $\mathrm{w}$ przestrzeni, komunikacji i relacji $\mathrm{z}$ innymi osobami, podejmowania aktywności zawodowej czy angażowania się w działalność społeczną. Nie pozostaje także bez wpływu na procesy samorealizacji i rozwijania autonomii osobowej i społecznej.

Uwzględniając poważne ograniczenia funkcjonowania dorosłych osób niewidomych przyjęto, że świadoma autonomia osoby

${ }_{10}$ M. Zaorska, Tyflopedagog wobec problemu aktywności życiowej - zawodowej i prozawodowej osób dorostych z niepetnosprawnościa wzrokowa, Wydawnictwo Edukacyjne Akapit, Toruń 2015, s. 11. 
niewidomej, umożliwiająca i warunkująca pełnienie zadań wieku dorosłego, wymaga:

- niezależności $\mathrm{w}$ zakresie orientowania się $\mathrm{w}$ przestrzeni i samodzielnego poruszania się w niej,

- samodzielności w zakresie wykonywania czynności dnia codziennego,

- swobodnego dostępu do informacji i możliwości komunikowania się,

- podejmowania spełniającej oczekiwania aktywności zawodowej,

- satysfakcjonującej aktywności rodzinnej, społecznej, kulturalnej.

Samodzielne i bezpieczne funkcjonowanie dorosłej osoby niewidomej w przestrzeni publicznej uwarunkowane jest dobrze zaprojektowaną i starannie realizowaną koncepcją rozwijania orientacji przestrzennej i samodzielnego poruszania się. W przypadku niepełnosprawności wzroku obecnej od wczesnego dzieciństwa warunkuje ją proces uczenia się przestrzeni, planowania i realizowania w niej własnego ruchu, zapoczątkowany we wczesnym okresie życia, wspomagany w okresie przedszkolnym, zintensyfikowany w okresie nauki szkolnej, dostosowany do potrzeb i możliwości osoby na różnych poziomach edukacji. Proces ten powinien prowadzić do osiągnięcia optymalnego poziomu umiejętności warunkującego niezależność w zakresie orientacji i lokomocji w wieku dorosłym. Koncepcja rozwijania orientacji w przestrzeni i samodzielnego poruszania się, w warunkach polskich realizowana jest $\mathrm{w}$ zadowalającym stopniu jedynie w szkolnictwie segregacyjnym. Znaczne ograniczenia $\mathrm{w}$ dostępie do wspomagania rozwoju umiejętności w zakresie orientacji przestrzennej mają dzieci uczące się w systemie niesegregacyjnym, co wynika z braku rozwiązań systemowych w tym zakresie, jak również lokalnie - z braku dostępu do nauczyciela orientacji przestrzennej i samodzielnego poruszania się. Brak wspomagania tej sfery rozwoju zawsze będzie oznaczał zależność od innych, a tym samym wpływał na ograniczoną autonomię osoby z niepełnosprawnością wzroku również w innych obszarach funkcjonowania. 
Z kolei osoba ociemniała, która utraciła wzrok w wieku dorosłym, doświadcza poważnych ograniczeń samodzielności przemieszczania się i funkcjonowania i potrzebuje systematycznej rehabilitacji $\mathrm{w}$ tym zakresie - przede wszystkim wsparcia w uczeniu się bezwzrokowego interpretowania przestrzeni, orientowania się $w$ niej i samodzielnego poruszania ${ }^{11}$. Proces ten może zakończyć się sukcesem $\mathrm{w}$ postaci samodzielnego, bezpiecznego poruszania się $\mathrm{z}$ długą laską lub z psem przewodnikiem, wymaga to jednak rozwiązań systemowych ułatwiających dostęp do rehabilitacji, które obecnie można by określić jako znikome. Częściową odpowiedzią na brak planowych, systemowych rozwiązań $\mathrm{w}$ zakresie oddziaływań edukacyjno-rehabilitacyjnych adresowanych do osób tracących wzrok jest wsparcie oferowane $w$ tym zakresie przez niektóre organizacje pozarządowe. Turnusy rehabilitacyjne i kursy organizowane przez Polski Związek Niewidomych, stowarzyszenia i fundacje (których działalność często inicjowana jest przez osoby z niepełnosprawnością wzroku) częściowo zaspokajają $\mathrm{w}$ tym zakresie potrzeby osób dorosłych.

Niezależność w kontekście samodzielnego codziennego funkcjonowania (prowadzenie domu, czynności samoobsługowe, przygotowywanie posiłków itp.), podobnie jak kwestie związane $\mathrm{z}$ samodzielnym poruszaniem się, warunkuje satysfakcjonującą autonomię. Dzieci z wrodzoną niepełnosprawnością wzroku, uczące się $\mathrm{w}$ ośrodkach szkolno-wychowawczych, realizują programy ukierunkowane na stopniowe zwiększanie samodzielności $\mathrm{w}$ zakresie czynności codziennych. Niestety, w placówkach o charakterze integracyjnym i włączającym nie przywiązuje się wagi do tego aspektu wychowawczo-edukacyjnego. Natomiast metodycznie prowadzone przygotowanie dziecka, a później młodego człowieka, pozwala na osiągnięcie wysokiego poziomu niezależności $\mathrm{w}$ tej sferze. $\mathrm{W}$ tej sytuacji realizacja tego zadania zostaje przeniesiona na środowisko

${ }^{11}$ R. Welsh, Teaching Orientation and Mobility to Adults, [w:] Foundations of Orientation and Mobility. Volume II: Instructional Strategies and Practical Applications, red. W.R. Wiener, R.L. Welsh, B.B. Blasch, AFB Press, New York 2010, s. 264-265. 
rodzinne. Należy jednak podkreślić, że podczas gdy dzieci posługujące się wzrokiem umiejętności związane z codziennym prowadzeniem gospodarstwa domowego przyswajają niejako mimochodem, naśladując działania innych osób, to dzieci i dorosłe osoby niewidome wymagają do ich uczenia się odpowiednio zorganizowanego procesu edukacyjnego. Renata Nowacka-Pyrlik ${ }^{12}$ podkreśla, że osoba tracąca możliwości wzrokowe i w związku z tym często doświadczająca poczucia bezradności (np. w sytuacji, kiedy nie potrafi samodzielnie przygotować posiłku, nalać herbaty bez obawy czy się nie sparzy, zrobić zakupów itp.) i całkowitej zależności od innych, często stawia pod znakiem zapytania możliwości dalszego funkcjonowania rodzinnego, zawodowego czy społecznego. Wymaga zatem pomocy, nie tylko psychologicznej - w sytuacji doświadczonej straty, ale także wsparcia w zakresie przywracania sprawności codziennego funkcjonowania. Celem działań wspomagających jest uzyskanie maksymalnej samodzielności w życiu codziennym i aktywne pełnienie funkcji społecznych oraz wzmocnienie wiary we własne możliwości i rozszerzanie autonomii. Opanowanie technik bezwzrokowego wykonywania codziennych czynności warunkuje sukces i powodzenie w dalszym procesie rehabilitacyjnym. Możliwość samodzielnego poruszania się, jak również kreatywnego rozwiązywania problemów związanych z życiem codziennym wpływa pozytywnie także na inne sfery funkcjonowania - rodzinną, zawodową, społeczną.

Osoba niewidoma potrzebuje rozwiązań ułatwiających, a niekiedy umożliwiających bezwzrokowy dostęp do informacji i wykonywania rozmaitych zadań. Pomocne są tu technologie wspomagające (asystujące), które mogą zaspokajać potrzeby osób niewidomych i słabowidzących podczas realizacji rozmaitych zadań. Jarosław Wiazowski ${ }^{13}$ określa technologie wspomagające jako specjalistyczne

12 R. Nowacka-Pyrlik, Rehabilitacja podstawowa osób niewidomych i stabowidzących dorostych, zwłaszcza w starszym wieku, na podstawie doświadczeń z pracy w ramach programu realizowanego w Centralnej Przychodni Polskiego Zwiąku Niewidomych w Warszawie, „Kontaktologia i Optyka Okulistyczna” 2008, nr 3, s. 35.

$13 \mathrm{~J}$. Wiazowski, Proces efektywnego doboru technologii wspierajacych edukację osób niewidomych i stabowidzących, [w:] Tyflopedagogika wobec wspótczesnej przestrzeni eduka- 
narzędzia o różnym stopniu złożoności, dające możliwość partycypacji w zadaniach, których realizacja bez takiego wsparcia byłaby utrudniona, a nawet niemożliwa dla osoby z niepełnosprawnością wzroku. Rozwiązaniami ułatwiającymi dostęp do informacji są m.in. oprogramowanie udźwiękawiające, łączenie technologii wspomagającej z uniwersalną, urządzenia uniwersalne z funkcjami dostępności dla osób niewidomych. Jak zauważa Małgorzata Paplińska14, pomoce elektroniczne oparte na kompensacyjnej roli zmysłów umożliwiają osobie niewidomej samodzielny i niezależny dostęp do słowa pisanego. Sprzyjają one redukowaniu poczucia odrębności w dostępie do informacji. Należy podkreślić, że nie tylko wybór odpowiednich narzędzi pozyskiwania informacji i komunikacji, ale także wsparcie w skutecznym korzystaniu z nich (szkolenia, kursy) warunkują samodzielność w tym zakresie. Realny dostęp do rozwiązań i szkoleń mają przede wszystkim uczniowie, studenci i osoby niewidome aktywne zawodowo. Szeroki asortyment technologii wspomagających sprzyja usamodzielnianiu się osób z niepełnosprawnością wzroku.

Praca zawodowa stanowi dla osoby $\mathrm{z}$ niepełnosprawnością wzroku nie tylko źródło utrzymania, jest też istotnym czynnikiem rozwoju osobowościowego i społecznego. Satysfakcjonująca aktywność zawodowa to niewątpliwie możliwość zatrudnienia na otwartym rynku pracy i zatrudnienie na standardowych warunkach, kiedy osoba niewidoma przechodzi ten sam proces rekrutacyjny i otrzymuje takie same zadania jak osoba w pełni sprawna15. Taka forma zatrudnienia jest dostępna dla niewielu osób niewidomych.

cyjno-rehabilitacyjnej, red. K. Czerwińska, M. Paplińska, M. Walkiewicz-Krutak, Wydawnictwo Akademii Pedagogiki Specjalnej, Warszawa 2015, s. 163.

${ }^{14}$ M. Paplińska, Konsekwencje wynikające z braku wzroku, [w:] Edukacja równych szans. Uczeń $i$ student $z$ dysfunkcja wzroku - nowe podejście, nowe możliwości, red. M. Paplińska, Uniwersytet Warszawski, Warszawa 2008, s. 18.

${ }^{15}$ E. Wojtasiak, Aktywizacja zawodowa istota procesu kompleksowej rehabilitacji, [w:] Poradnictwo zawodowe w rehabilitacji osób niepetnosprawnych, red. E. Wojtasiak, M. Wolan-Nowakowska, Wydawnictwo Akademii Pedagogiki Specjalnej, Warszawa 2012, s. 132. 
$\mathrm{Na}$ otwartym rynku pracy możliwe jest także zatrudnienie na stanowisku dostosowanym - dla osoby z niepełnosprawnością wzroku może to być m.in. wykorzystanie specjalistycznego oprogramowania, pomocy optycznych i/lub elektronicznych, dodatkowego oświetlenia. Rodzaj i zakres stosowanych adaptacji jest wypadkową potrzeb pracownika $\mathrm{z}$ niepełnosprawnością wzroku i wymagań stanowiska pracy ${ }^{16}$. Inną formą jest zatrudnienie wspomagane, kiedy $\mathrm{w}$ znalezieniu i utrzymaniu pracy pomaga odpowiednio przeszkolony trener. Zakres możliwości wspomagania osób z niepełnosprawnością wzroku w poszukiwaniu pracy i podejmowaniu aktywności zawodowej szeroko opisała Marzenna Zaorska ${ }^{17}$, akcentując rolę i zadania tyflopedagoga $\mathrm{w}$ tym procesie.

Aktywność społeczna osób niewidomych jest determinowana gotowością środowiska do współpracy z osobami niepełnosprawnymi w zakresie rozmaitych inicjatyw społecznych. Istotne znaczenie ma tu emancypowanie środowiska społecznego, zwłaszcza lokalnego, do uwalniania się ze stereotypowego postrzegania osób niewidomych i włączania ich, jako równoprawnych członków społeczności, w realizację zadań obywatelskich i innych aktywności.

Z kolei uczestnictwo osób niepełnosprawnych w życiu kulturalnym zdaniem Leszka Plocha ${ }^{18}$ warunkują cechy demograficznospołeczne (np. dostęp do wydarzeń kulturalnych), indywidualne (np. wiek, wykształcenie), jak i stopień niepełnosprawności. Autor podkreśla rolę twórczego udziału osób niepełnosprawnych w tworzeniu dóbr kultury, który daje możliwości pełnego wyrażania siebie i wnoszenia własnych cennych propozycji twórczych i kulturalnych.

Zakres korzystania z dóbr kultury przez osoby z niepełnosprawnością wzroku uwarunkowany jest ich udostępnianiem przez

${ }^{16}$ M. Wolan-Nowakowska, D. Opioła, Możliwości i ograniczenia wykonywania pracy przez osoby z niepetnosprawnością, [w:] Poradnictwo zawodowe w rehabilitacji osób niepetnosprawnych, red. E. Wojtasiak, M. Wolan-Nowakowska, Wydawnictwo Akademii Pedagogiki Specjalnej, Warszawa 2012, s. 37.

17 M. Zaorska, op. cit.

${ }^{18}$ L. Ploch, W kręgu kultury osób niepetnosprawnych, „Socius” 2009, nr 3, s. 2. 
instytucje kulturalne. Osoby niewidome mają ograniczone możliwości uczestniczenia w wydarzeniach, które oferują kina, teatry, muzea, galerie i inne instytucje kulturalne. Nie mogą korzystać $\mathrm{z}$ nich $\mathrm{w}$ pełni, ponieważ nie są $\mathrm{w}$ stanie odbierać treści wizualnych (osoby niewidome) lub odbierają je częściowo (osoby słabowidzące), co sprawia, że przekaz artystyczny może być nie w pełni zrozumiały dla odbiorcy z niepełnosprawnością wzroku. Wykorzystanie rozwijającej się $\mathrm{w}$ ostatnich latach audiodeskrypcji sprawia, że niektóre wydarzenia kulturalne stają się dostępne również dla osób z niepełnosprawnością wzroku. Audiodeskrypcja jest coraz częściej wykorzystywana nie tylko do opisywania sztuk teatralnych i filmów, lecz także wytworów plastycznych, fotografii czy też wydarzeń sportowych. Jej dynamiczny rozwój jest efektem działań i starań środowiska osób niewidomych. Jak podkreśla Robert Więckowski ${ }^{19}$, tworzenie audiodeskrypcji jest działalnością o dużej wartości społecznej, wychodzącą naprzeciw oczekiwaniom osób niewidomych i słabowidzących.

Rozwinięcie autonomii w okresie dorosłości wymaga wsparcia ze strony rodziny, osób bliskich, jak również pomocy specjalistów dobrze zaplanowanego i prowadzonego procesu edukacyjno-rehabilitacyjnego. Czynnikiem motywującym do zwiększania autonomii jest często wsparcie innych osób doświadczających podobnych problemów (wsparcie środowiska osób niewidomych, np. działalność fundacji powoływanych przez osoby niewidome, działających na rzecz osób z niepełnosprawnością wzroku).

\section{Ku wspólnej emancypacji - wzajemne wspieranie się osób z niepełnosprawnością wzroku w drodze do autonomii i podmiotowości}

Proces emancypacji osoby może zachodzić na tle emancypacji grupy doświadczającej podobnych ograniczeń i zniewoleń i z jej

${ }^{19}$ R. Więckowski, Audiodeskrypcja piękna, „Przekładaniec” 2014, nr 28, s. 123. 
wsparciem. Amadeusz Krause ${ }^{20}$ wskazał na aktywizację wyzwalającą tożsamość grupową i na istotną rolę liderów środowisk osób $\mathrm{z}$ niepełnosprawnością $\mathrm{w}$ tym procesie. Należy tu podkreślić rosnące znaczenie fundacji i stowarzyszeń powoływanych przez osoby $\mathrm{z}$ niepełnosprawnością wzroku (sprawnie radzące sobie z codziennym funkcjonowaniem i dostrzegające potrzebę dzielenia się swoim osobistym doświadczeniem, dostrzegające potrzeby zmian). Mają one aspiracje podejmowania aktywności ukierunkowanych na zmienianie warunków funkcjonowania osób niewidomych i rozszerzanie ich realnej autonomii. Podejmują one najwyższy poziom zaangażowania w emancypację, określony przez Marię CzerepaniakWalczak jako „dążenia”, czyli:

(...) świadome działanie ukierunkowane na uwalnianie się od ograniczeń i korzystanie $\mathrm{z}$ należnych praw ${ }^{21}$.

Przykładem organizacji zrzeszającej osoby z niepełnosprawnością wzroku, która od początku istnienia (od 1940 r.), realizuje idee emancypacji, jest National Federation of the Blind (NFB) działająca w USA. Już motto NFB, którego fragment brzmi:

(...) niewidzenie nie jest cechą, która determinuje Ciebie i Twoją przyszłość... Możesz żyć życiem jakim chcesz, brak wzroku nie jest tym, co Cię powstrzymuje ${ }^{22}$,

sygnalizuje silne dążenie środowiska osób niewidomych do niezależności i godnego funkcjonowania. Wybrane cele organizacji można scharakteryzować jako pomoc osobom niewidomym w osiąganiu pewności siebie i szacunku dla siebie (idee podmiotowości osoby), działanie jako narzędzie zbiorowego wyrażania potrzeb środowiska osób niewidomych (podmiotowość grupy), ale także edukowanie społeczeństwa na temat konsekwencji niewidzenia, propagowanie informacji dotyczących realnych możliwości osób

\footnotetext{
20 A. Krause, op. cit., s. 207.

${ }^{21}$ M. Czerepaniak-Walczak, op. cit., s. 146.

22 www.nfb.org [22.10.2015].
} 
niewidomych, np. przekonania, że osoba niewidoma może w wielu płaszczyznach życia konkurować z osobą widzącą na zasadach równości.

Polską fundacją, aktywnie podejmującą wyzwania emancypacyjne, jest Fundacja Vis Maior, działająca na rzecz osób niewidomych i słabowidzących od 2002 r. Realizowane przez Fundację cele jej członkowie określają następująco:

Wspieramy osoby z niepełnosprawnością wzroku oraz ich rodziny $\mathrm{w}$ pokonywaniu ograniczeń związanych z niepełnosprawnością. Pomagamy odnaleźć się po utracie widzenia i pokazujemy jak w takiej sytuacji funkcjonować ${ }^{23}$.

Nadrzędnym celem Fundacji Vis Maior jest wzmacnianie dążenia osób z niepełnosprawnością wzroku do osiągania samodzielności. Fundacja realizuje je m.in. poprzez wsparcie psychologiczne, szkolenia w zakresie poruszania się z długą laską lub z psem przewodnikiem, pomoc w nauce czynności dnia codziennego i alfabetu Breille'a, szkolenia z zakresu obsługi komputera wyposażonego w specjalistyczne oprogramowanie. Oferuje także pomoc w przygotowaniu się do skutecznego poszukiwania pracy, informuje o ofercie kulturalnej i sportowej dostępnej dla osób niewidomych i słabowidzących. Większość z wymienionych działań prowadzą osoby z niepełnosprawnością wzroku. Na uwagę zasługuje kontekst społecznej działalności Fundacji Vis Maior, np. przyczynienie się do nowelizacji ustawy o rehabilitacji zawodowej i społecznej oraz zatrudnieniu osób niepełnosprawnych, która obecnie daje prawo osobom niewidomym poruszającym się z psami przewodnikami wejścia do wszystkich budynków użyteczności publicznej, co wcześniej budziło kontrowersyjny sprzeciw przedstawicieli wielu instytucji. Członkowie Fundacji brali także udział w pracach nad nowelizacją Kodeksu Wyborczego, które doprowadziły do wypracowania rozwiązań umożliwiających osobom z niepełnosprawnością wzroku pełnoprawny udział w wyborach. Fundacja prowadzi zatem za-

${ }^{23}$ www.fundacjavismaior.pl [23.10.2015]. 
równo działania nakierowane na realizację potrzeby rozwoju autonomii jednostki, jak również zajmuje się rzecznictwem praw osób z niepełnosprawnością wzroku i monitoringiem przestrzegania tych praw. Przedstawiciele Fundacji tak scharakteryzowali swoją działalność:

W Fundacji Vis Maior postrzegamy osoby niepełnosprawne jako pełnoprawnych obywateli, którzy mogą o sobie decydować i uczestniczyć we wszystkich dziedzinach życia ${ }^{24}$.

Organizacja realizująca podobne dążenia, to także Fundacja Instytut Rozwoju Regionalnego (FIRR), której misją jest zapewnienie równych praw osobom z niepełnosprawnościami w Polsce 25.

FIRR wspiera szkoleniowo i doradczo osoby z niepełnosprawnością $\mathrm{w}$ niezależnym życiu, promuje korzystanie $\mathrm{z}$ najnowszych technologii. Inne fundacje o podobnym profilu działalności, to m.in. Fundacja Polskich Niewidomych i Słabowidzących Trakt ${ }^{26}$ oraz Fundacja na Rzecz Osób Niewidomych i Słabowidzących VEGA realizująca np. projekt „Bardziej samodzielni - bardziej niezależni” 27.

\section{Podsumowanie}

Wzmacnianie dążenia do autonomii osób z niepełnosprawnością wzroku i ułatwianie jej osiągnięcia powinno być jednym z ważniejszych celów oddziaływań edukacyjno-rehabilitacyjnych. Niezależność w różnych obszarach codziennego funkcjonowania ułatwia pełnienie funkcji rodzinnych i społecznych, wykonywanie obowiązków zawodowych, wzmacnia aspiracje wyzwalania się z ograniczeń wynikających z konsekwencji doświadczanej dysfunkcji. Wspólnie realizowane idee podmiotowości osoby i podmiotowości

\footnotetext{
${ }^{24}$ wWw.fundacjavismaior.pl [23.10.2015].

${ }^{25}$ www.firr.org.pl [23.10.2015].

${ }^{26}$ www.trakt.org.pl [23.10.2015].

${ }^{27}$ www.fundacja-vega.pl [23.10.2015].
} 
grupy przynoszą wymierne efekty w postaci zmian regulacji prawnych i społecznego postrzegania niepełnosprawności, przede wszystkim zaś sprzyjają indywidualnemu rozwojowi jednostki. Założenia i cele współcześnie działających fundacji, powoływanych przez osoby z niepełnosprawnością wzroku, wskazują na silne dążenia do rozszerzania autonomii i wzmacniania poczucia podmiotowości w obrębie tego środowiska i poszczególnych jego jednostek. Konkretne formy pomocy, wzajemne wspieranie się oraz odpowiedni przykład ze strony tych osób niewidomych, które osiągnęły sukces w niezależnym funkcjonowaniu, są skutecznymi motywatorami, które pobudzają osoby mające słabszą determinację i mniejszą wiarę we własne możliwości do podejmowania odważnych decyzji i dokonywania wyborów zgodnie z własnymi pragnieniami. Podmiotowość, autonomia i emancypacja osób z niepełnosprawnością wzroku nie dokonają się jednak w pełni, jeśli ich dążeniom emancypacyjnym nie będzie towarzyszyła otwartość i życzliwość ze strony zarówno najbliższych (rodziny, przyjaciół), jak i szerzej rozumianego społeczeństwa.

\section{Bibliografia}

Brzezińska A.I., Hejmanowski S., Okres późnej dorostości. Jak rozpoznać ryzyko i jak pomagać, [w:] Psychologiczne portrety człowieka, red. A.I. Brzezińska, Gdańskie Wydawnictwo Psychologiczne, Gdańsk 2005.

Cytowska B., Trudne drogi adaptacji. Watki emancypacyjne w analizie sytuacji dorostych osób z niepetnosprawnościa intelektualna we wspótczesnym spoteczeństwie polskim, Oficyna Wydawnicza „Impuls”, Kraków 2012.

Czerepaniak-Walczak M., Pedagogika emancypacyjna, Gdańskie Wydawnictwo Psychologiczne, Gdańsk 2006.

Dykcik W., Problemy autonomii, integracji społecznej i normalizacji życia osób niepetnosprawnych w środowisku, [w:] Pedagogika specjalna. Praca zbiorowa, red. W. Dykcik, Wydawnictwo Naukowe Uniwersytetu im. Adama Mickiewicza, Poznań 2001.

Krause A., Wspótczesne paradygmaty pedagogiki specjalnej, Oficyna Wydawnicza „Impuls", Kraków 2010.

Nowacka-Pyrlik R., Rehabilitacja podstawowa osób niewidomych $i$ stabowidzacych dorostych, zwłaszcza $w$ starszym wieku, na podstawie doświadczeń z pracy $w$ ramach pro- 
gramu realizowanego w Centralnej Przychodni Polskiego Zwiazku Niewidomych w Warszawie, „Kontaktologia i Optyka Okulistyczna” 2008, nr 3.

Paplińska M., Konsekwencje wynikające z braku wzroku, [w:] Edukacja równych szans. Uczeń $i$ student $z$ dysfunkcja wzroku - nowe podejście, nowe możliwości, red. M. Paplińska, Uniwersytet Warszawski, Warszawa 2008.

Ploch L., W kręgu kultury osób niepetnosprawnych, „Socius” 2009, nr 3, s. 2.

Welsh R., Teaching Orientation and Mobility to Adults, [w:] Foundations of Orientation and Mobility. Volume II: Instructional Strategies and Practical Applications, red. W.R. Wiener, R.L. Welsh, B.B. Blasch, AFB Press, New York 2010.

Wiazowski J., Proces efektywnego doboru technologii wspierających edukację osób niewidomych $i$ stabowidzacych, [w:] Tyflopedagogika wobec wspótczesnej przestrzeni edukacyjno-rehabilitacyjnej, red. K. Czerwińska, M. Paplińska, M. Walkiewicz-Krutak, Wydawnictwo Akademii Pedagogiki Specjalnej, Warszawa 2015.

Więckowski R., Audiodeskrypcja piękna, „Przekładaniec” 2014, nr 28.

Wojtasiak E., Aktywizacja zawodowa istota procesu kompleksowej rehabilitacji, [w:] Poradnictwo zawodowe w rehabilitacji osób niepetnosprawnych, red. E. Wojtasiak, M. Wolan-Nowakowska, Wydawnictwo Akademii Pedagogiki Specjalnej, Warszawa 2012.

Wolan-Nowakowska M., Opioła D., Możliwości i ograniczenia wykonywania pracy przez osoby z niepetnosprawnościq, [w:] Poradnictwo zawodowe w rehabilitacji osób niepetnosprawnych, red. E. Wojtasiak, M. Wolan-Nowakowska, Wydawnictwo Akademii Pedagogiki Specjalnej, Warszawa 2012.

Zaorska M., Tyflopedagog wobec problemu aktywności życiowej - zawodowej i prozawodowej osób dorostych z niepetnosprawnościa wzrokowa, Wydawnictwo Edukacyjne Akapit, Torun 2015.

\section{Źródła internetowe}

National Federation of the Blind, www.nfb.org [22.10.2015].

Fundacja Vis Maior, www.fundacjavismaior.pl [23.10.2015].

Fundacja Instytut Rozwoju Regionalnego, www.firr.org.pl [23.10.2015].

Fundacja Polskich Niewidomych i Słabowidzących "Trakt”, www.trakt.org.pl [23.10.2015].

Fundacja na Rzecz Osób Niewidomych i Słabowidzących VEGA, www.fundacjavega.pl [23.10.2015]. 